\title{
Effects of Platycodin D on apoptosis, migration, invasion and cell cycle arrest of gallbladder cancer cells
}

\author{
XIAOYU ZHANG $^{1 *}$, TIANYU ZHAI $^{1,2^{*}}$, ZHENYU HEI $^{1}$, DI ZHOU $^{1}$, \\ LONGYANG JIN ${ }^{3}$, CHAO HAN ${ }^{4}$ and JIANDONG WANG ${ }^{1}$ \\ ${ }^{1}$ Department of General Surgery and Laboratory of General Surgery, Xinhua Hospital Affiliated to Shanghai Jiao Tong \\ University School of Medicine; ${ }^{2}$ Shanghai Key Laboratory of Biliary Tract Disease Research, Xinhua Hospital \\ Affiliated to Shanghai Jiao Tong university School of Medicine, Shanghai 200092; ${ }^{3}$ Department of Colorectal Surgery, \\ The Sixth Affiliated Hospital of Sun Yat-sen University, Guangzhou, Guangdong 510655; ${ }^{4}$ Department of General \\ Surgery, Shanghai General Hospital, Shanghai Jiao Tong University School of Medicine, Shanghai 200080, P.R. China
}

Received December 30, 2019; Accepted July 15, 2020

DOI: $10.3892 / \mathrm{ol} .2020 .12174$

\begin{abstract}
Platycodin D (PD) is a triterpenoid saponin that exists in the roots of Platycodonis. It exhibits evident growth inhibitory effects and potent cytotoxicity against multiple types of cancer. Gallbladder cancer (GBC) is the most common malignant disease of the biliary tract system. Patients with GBC usually have limited available treatment strategies and a poor prognosis. The present study investigated the antitumor effects of PD on human GBC cells in vitro and its underlying molecular mechanisms of action. The results indicated that PD, as assessed using MTT and colony forming assays, induced evident growth inhibition. Flow cytometry indicated that PD robustly induced apoptosis and blocked GBC cells at the $\mathrm{G}_{2} / \mathrm{M}$ phase. Cell migration and invasion assays demonstrated that PD effectively inhibited the migratory and invasive abilities of GBC cell lines Western blotting indicated that PD may initiate mitochondrial destruction in GBC cells through the JNK signaling pathway, thereby inducing apoptosis. The present results indicated that PD may exhibit antitumor effects by inducing apoptosis; inhibiting migration and invasion; and affecting the cell cycle in GBC cells. Therefore, PD has the potential to become a novel antitumor drug for GBC therapy.
\end{abstract}

Correspondence to: Professor Jiandong Wang, Department of General Surgery and Laboratory of General Surgery, Xinhua Hospital Affiliated to Shanghai Jiao Tong University School of Medicine, 1665 Kongjiang Road, Shanghai 200092, P.R. China

E-mail: wangjiandong@xinhuamed.com.cn

${ }^{*}$ Contributed equally

Key words: Platycodin D, human gallbladder cancer, apoptosis, migration, invasion, cell cycle arrest

\section{Introduction}

Gallbladder cancer (GBC) has the highest incidence among malignant tumors of the biliary tract system, ranking fifth among the common malignant diseases of the digestive system worldwide (1), with an age-standardized rate (ASR) of 2.2 per 100,000 in 2012 (2). Due to the difficulty of early diagnosis, rapid invasion and metastasis are common, while treatment strategies are limited, resulting in patients with GBC having a poor prognosis $(3,4)$. Therefore, the development of an effective agent that can prolong the survival of patients with GBC is urgently required. There is a long history of the use of plants to treat cancer. Studies have revealed a vast chemical diversity in numerous plants, which remain a notable source of antitumor drugs (5-8). Platycodin D (PD; Fig. 1) is a triterpenoid saponin extracted from Platycodonis (9). Previous studies have revealed that $\mathrm{PD}$ is a promising anticancer compound that can inhibit various cancer cell lines, including prostate cancer (10), glioma (11), leukemia (12), liver cancer (13), breast cancer (14) and gastric carcinoma (15), through various mechanisms including proliferation and metastasis inhibition (16,17), apoptosis induction (10), cell cycle arrest (12) and autophagy (18). However, the effect of PD on GBC cell lines remains unknown. Therefore, the present study aimed to explore the antitumor activity of PD on GBC cells and to determine its potential molecular mechanisms of action, with the goal of providing a promising drug for the future treatment of GBC.

\section{Materials and methods}

Chemicals andreagents.PD (>98\%,PubChem CID:132399081) was purchased from Shanghai Yuanye Biotechnology Co., Ltd. It was dissolved in PBS to obtain a stock solution $(100 \mu \mathrm{mol} / \mathrm{l})$, then stored at $-20^{\circ} \mathrm{C}$. MTT and Hoechst 33342 were purchased from Sigma-Aldrich; Merck KGaA. FITC Annexin V Apoptosis Detection kit I was purchased from BD Biosciences. Primary antibodies against cleaved caspase-9 (1:1,000; cat. no. 9505), cleaved caspase-3 (1:1,000; cat. no. 9661), Bax (1:1,000; cat. no. 5023), Bcl-2 (1:1,000; cat. no. 4223), SAPK 
(stress-activated protein kinase)/JNK (1:1,000; cat. no. 9252), phosphorylated-SAPK/JNK (p-JNK; 1:1,000; cat. no. 9251), matrix metalloproteinase (MMP)-2 (1:1,000; cat. no. 87809), MMP-9 (1:1,000; cat. no. 3852), cyclin B1 (1:1,000; cat. no. 4138), cytochrome $c(1: 1,000$; cat. no. 4272) and $\beta$-tubulin (1:1,000; cat. no. 2146), and all secondary antibodies (1:1,000; cat. no. 7074) were purchased from Cell Signaling Technology, Inc. The same secondary antibody was used for all primary antibodies. The antibody against cyclin-dependent kinase 1 (CDK1; 1:1,000; cat. no. ab133327) was purchased from Abcam.

Cell lines and cell culture. The human GBC NOZ, GBC-SD and SGC-996 cell lines were obtained from the The Cell Bank of Type Culture Collection of the Chinese Academy of Sciences. The cells were maintained in DMEM supplemented with 10\% FBS (both Gibco; Thermo Fisher Scientific, Inc.), $100 \mu \mathrm{g} / \mathrm{ml}$ streptomycin and $100 \mathrm{U} / \mathrm{ml}$ penicillin. All cells were cultured at $37^{\circ} \mathrm{C}$ in a humidified atmosphere with $5 \% \mathrm{CO}_{2}$.

MTT assay. GBC cells were added into 96-well plates at a density of $2 \times 10^{3}$ cells/well and cultured overnight at $37^{\circ} \mathrm{C}$ and $5 \% \mathrm{CO}_{2}$. Subsequently, different concentrations of $\mathrm{PD}(0,5,10$, 15,20 and $25 \mu \mathrm{mol} / \mathrm{l}$ ) were added to each well, and the cells were cultured for 24,48 or $72 \mathrm{~h}$, separately. MTT $(5 \mathrm{mg} / \mathrm{ml})$ solution was added to the wells (10 $\mu \mathrm{l} /$ well) and incubated at $37^{\circ} \mathrm{C}$ for $4 \mathrm{~h}$. The culture medium was then replaced with DMSO (100 $\mu \mathrm{l} /$ well) to dissolve the purple formazan and a microplate reader (BioTek Instruments, Inc.) was used to measure the absorbance at $490 \mathrm{~nm}$.

Colony forming assay. NOZ and GBC-SD cells were collected and counted manually. A total of 600 cells/well were added into 6-well plates (Corning Inc.). Subsequently, PD at different concentrations $(0,5,10$ and $15 \mu \mathrm{mol} / \mathrm{l})$ was used to treat the cells. The cells were treated for $\sim 14$ days. After treatment, the cells were fixed with $4 \%$ paraformaldehyde for $15 \mathrm{~min}$ and stained with $0.1 \%$ crystal violet (Sigma-Aldrich; Merck KGaA) for $15 \mathrm{~min}$ at room temperature. All colonies with $>50$ cells were recorded manually with a fluorescence microscope (magnification x40; Leica Microsystems GmbH).

Cell apoptosis assay. NOZ and GBC-SD cells were cultured with $\mathrm{PD}$ at various concentrations $(0,5,10$ and $15 \mu \mathrm{mol} / \mathrm{l})$ for $48 \mathrm{~h}$ at $37^{\circ} \mathrm{C}$ and $5 \% \mathrm{CO}_{2}$. After culturing, the cells were collected and washed with PBS. Next, the cells were diluted to the appropriate density $\left(10^{6}\right.$ cells $\left./ \mathrm{ml}\right)$ using a Annexin V binding buffer (BD Biosciences). The cell suspension $(200 \mu \mathrm{l})$ was gently mixed with Annexin V-FITC $(5 \mu \mathrm{l})$ (BD Biosciences) and PI (5 $\mu \mathrm{l})$ (BD Biosciences) and incubated for $15 \mathrm{~min}$ in the dark at room temperature, these were a part of the kit mentioned earlier and were used according to the manufacturer's protocol. Subsequently, $300 \mu \mathrm{l}$ of the binding buffer was added. Flow cytometry using a BD FACSCanto II (BD Biosciences) was used to analyze the sample within $1 \mathrm{~h}$ and BD FACSDiva Software v6.1.3 (BD Biosciences) was used to analyze the results.

Hoechst 33342 staining. NOZ and GBC-SD cells were added into 12 -well plates and incubated overnight at $37^{\circ} \mathrm{C}$ and

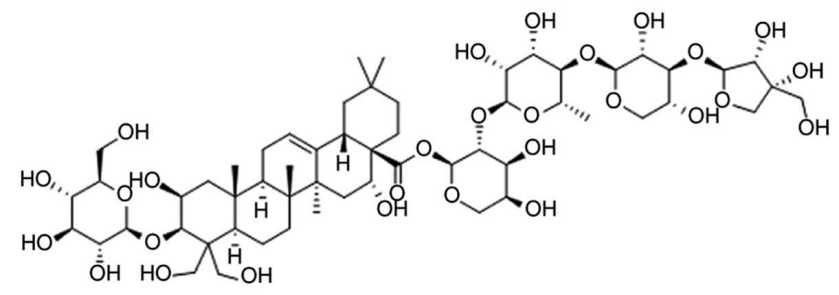

Figure 1. Chemical structure of Platycodin D.

$5 \% \mathrm{CO}_{2}$. Subsequently, PD at 0, 5, 10 and $15 \mu \mathrm{mol} / 1$ was added to the wells, and the plates were incubated for $48 \mathrm{~h}$ at $37^{\circ} \mathrm{C}$ and $5 \% \mathrm{CO}_{2}$. After treatment, the cells were stained with Hoechst 33342 for $30 \mathrm{~min}$ in the dark at $37^{\circ} \mathrm{C}$ and then washed with PBS. The cells were observed using a fluorescence microscope (magnification, x200; Leica Microsystems GmbH).

Mito-Tracker green staining. NOZ and GBC-SD cells were treated with different concentrations $(0,5,10$ and $15 \mu \mathrm{mol} / \mathrm{l})$ of $\mathrm{PD}$ for $48 \mathrm{~h}$ at $37^{\circ} \mathrm{C}$ and $5 \% \mathrm{CO}_{2}$. Subsequently, the cells were stained with Mito-Tracker green (Beyotime Institute of Biotechnology) at $37^{\circ} \mathrm{C}$ for $30 \mathrm{~min}$ in the dark. The cells were observed using a fluorescence microscope (magnification x100; Leica Microsystems GmbH).

Cell migration and invasion assay. Transwell plates with 24 wells (Corning Inc.) were used to perform cell migration and invasion assays. The upper chambers with or without Matrige ${ }^{\circledR}(1 \mathrm{mg} / \mathrm{ml})$ were dried at $37^{\circ} \mathrm{C}$ for $30 \mathrm{~min}$. NOZ and GBC-SD cells treated with PD $(0,5,10$ and $15 \mu \mathrm{mol} / \mathrm{l})$ for $48 \mathrm{~h}$ were collected and diluted in serum-free DMEM at a density of $2 \times 10^{5}$ cells $/ \mathrm{ml}$. Subsequently, $100 \mu \mathrm{l}$ of the cell suspension was added to the upper chambers. Simultaneously, $500 \mu 1$ of DMEM supplemented with $10 \%$ FBS was added to the lower chambers. After $24 \mathrm{~h}$, the cells on top of the membrane were removed using a cotton swab. The cells on the lower membrane were fixed with $4 \%$ paraformaldehyde for $15 \mathrm{~min}$ at room temperature, stained with crystal violet for $15 \mathrm{~min}$ at room temperature, and observed using a phase-contrast microscope (magnification, x100; Olympus Corporation). Five fields of vision were randomly selected per well.

Cell cycle analysis. For cell cycle analysis, the Cell Cycle and Apoptosis Analysis kit was used (Beyotime Institute of Biotechnology). NOZ and GBC-SD cells were seeded into 6-well plates and incubated overnight at $37^{\circ} \mathrm{C}$ and $5 \% \mathrm{CO}_{2}$. The supernatant was replaced with different concentrations $(0,5,10$ and $15 \mu \mathrm{mol} / \mathrm{l})$ of PD. After $48 \mathrm{~h}$ of incubation at $37^{\circ} \mathrm{C}$ and $5 \% \mathrm{CO}_{2}$, the cell layer was digested using trypsin, washed with cold PBS and fixed with $70 \%$ ethanol at $4^{\circ} \mathrm{C}$ for at least $2 \mathrm{~h}$ before storing at $4^{\circ} \mathrm{C}$ overnight. Subsequently, the cells were washed with cold PBS and resuspended in staining buffer. Next, $0.1 \mathrm{mg} / \mathrm{ml}$ RNase A and $0.1 \mathrm{mg} / \mathrm{ml}$ PI were added to the cell suspension. The staining buffer, RNase A and PI were part of the Cell Cycle and Apoptosis Analysis kit (Beyotime Institute of Biotechnology) and were used according to the manufacturer's instructions. The cells were analyzed using flow cytometry after incubation at $37^{\circ} \mathrm{C}$ in the dark for $30 \mathrm{~min}$. BD FACSDiva Software v6.1.3 (BD 


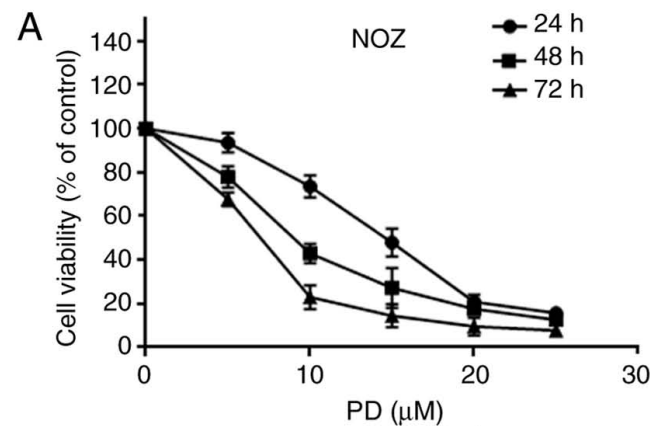

B
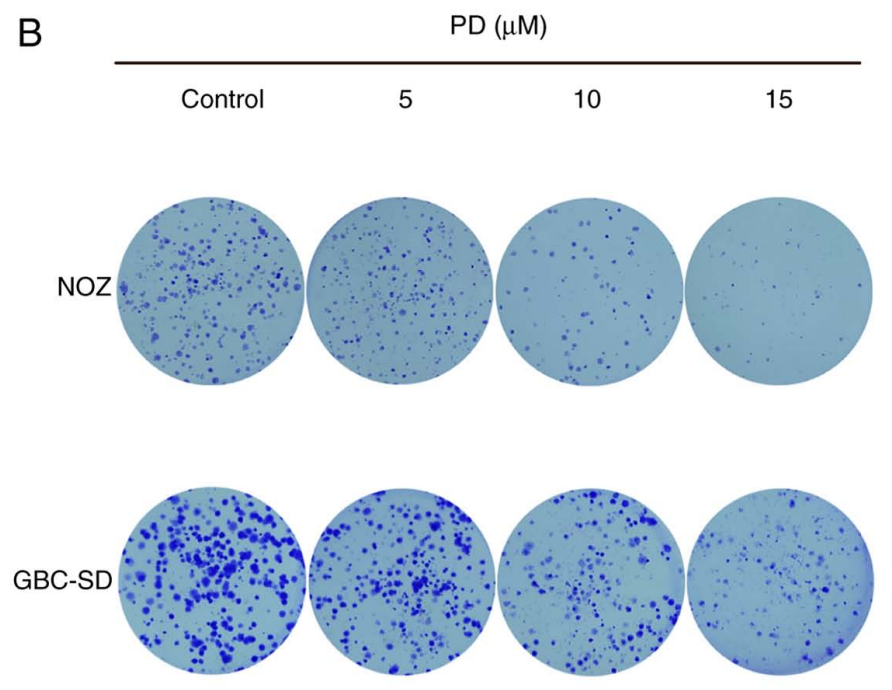
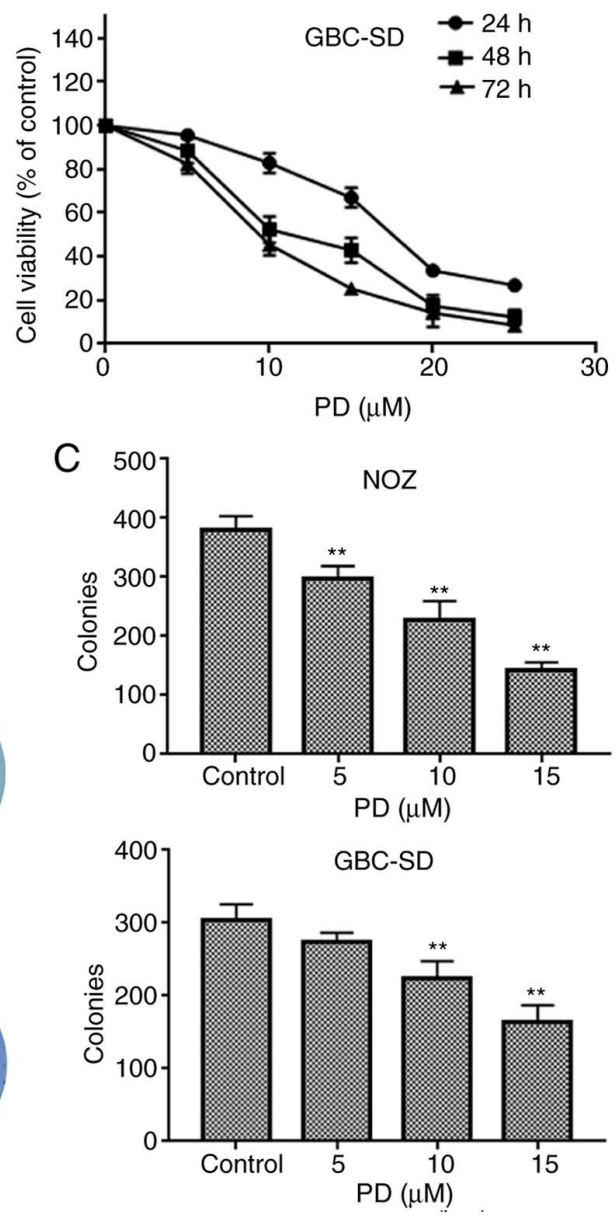

Figure 2. PD inhibits proliferation and colony formation in GBC cells. (A) MTT assay was used to detect the proliferation ability of PD-treated GBC cells after 24,48 and $72 \mathrm{~h}$. (B) NOZ and GBC-SD cells were treated with PD at 0, 5, 10 and $15 \mu \mathrm{mol} / 1$ for 14 days and stained with $0.1 \%$ crystal violet (magnification, $\mathrm{x} 40$ ). (C) Colonies with $>50$ cells were counted. The data is expressed as the mean $\pm \mathrm{SD}(\mathrm{n}=3)$. ${ }^{* *} \mathrm{P}<0.01$ vs. control. PD, Platycodin $\mathrm{D}$; GBC, gallbladder cancer.

Biosciences) was used to analyze the distribution of the cell cycle phases.

Western blot analysis. NOZ and GBC-SD cells treated with PD $(0,5,10$ and $15 \mu \mathrm{mol} / \mathrm{l})$ for $48 \mathrm{~h}$ were collected and washed with PBS. Total protein was extracted from the cells using RIPA buffer (Beyotime Institute of Biotechnology). After sonication $(15-25 \mathrm{KHz}, 25 \mathrm{sec}$ on ice), the mixture was centrifuged at $14,000 \mathrm{x}$ g for $20 \mathrm{~min}$ at $4^{\circ} \mathrm{C}$. Protein concentration was quantified using a bicinchoninic acid assay kit (Beyotime Institute of Biotechnology). Subsequently, the proteins (30 $\mu \mathrm{g} /$ lane) were separated via 10\% SDS-PAGE and transferred to PVDF membranes (EMD Millipore). After blocking with $5 \%$ skimmed milk for $1 \mathrm{~h}$ at room temperature, the membranes were incubated with the corresponding aforementioned primary antibodies at $4^{\circ} \mathrm{C}$ overnight. The membranes were washed three times with TBS supplemented with $0.1 \%$ Tween-20 (TBST) and incubated with horseradish peroxidase-conjugated goat anti-rabbit secondary antibodies (Cell Signaling Technology, Inc.) for $1 \mathrm{~h}$ at room temperature. Subsequently, the membranes were washed again with TBST three times and Millipore Western Blot Chemiluminescence HRP Substrate ECL Luminescent solution was added (EMD Millipore). The membranes were observed using the Gel Doc 2000 (Bio-Rad Laboratories, Inc.) and ImageJ software version 1.48 (National Institutes of Health) was used to quantify the densitometric values of the detected bands.

Statistical analysis. Each experiment was performed three times. The data was expressed as the mean \pm SD. Shapiro-Wilk normality tests were used to assess normality of quantitative variable distributions. If the variables followed a normal distribution, one-way ANOVAs followed by Dunnett's multiple comparisons test was performed using GraphPad Prism version 7.0 (GraphPad Software, Inc.) to analyze the results. Alternatively, Kruskal-Wallis test followed by Dunn's multiple comparisons test was used in cases where the samples were not normally distributed. $\mathrm{P}<0.05$ was considered to indicate a statistically significant difference.

\section{Results}

$P D$ inhibits proliferation and colony formation in $G B C$ cells. The MTT assay was used to detect the proliferative ability of PD-treated GBC cells. The results indicated that the proliferation of GBC cells decreased with an increased concentration of PD in a time-dependent manner. In NOZ and GBC-SD cells, the $\mathrm{IC}_{50}$ of PD was $\sim 10 \mu \mathrm{mol} / 1$ at $48 \mathrm{~h}$ (Fig. 2A). PD had a stronger inhibitory effect on NOZ and GBC-SD cells than on SGC-996 cells (Fig. S1); therefore, NOZ and GBC-SD cells 
A $\mathrm{PD}(\mu \mathrm{M})$
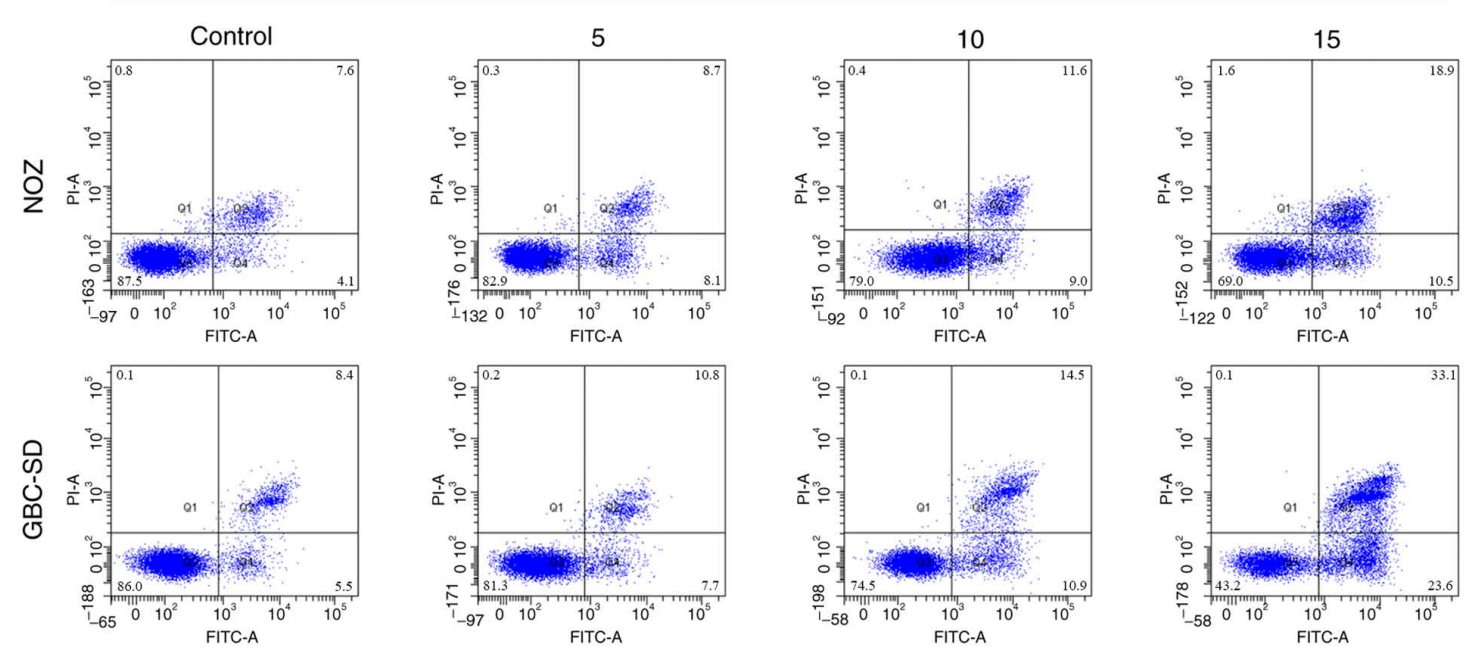

B

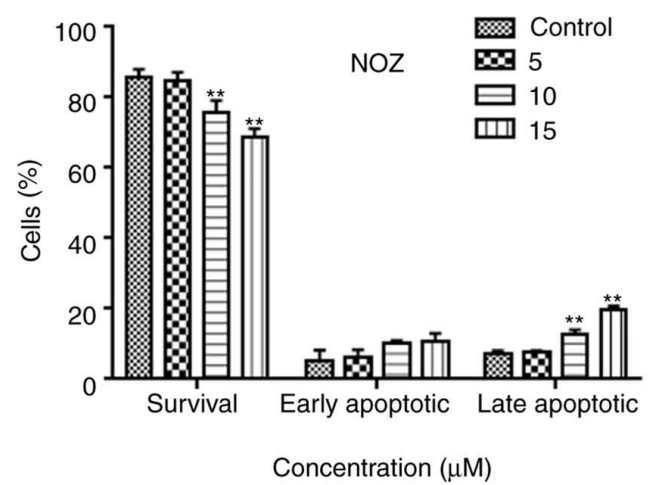

C
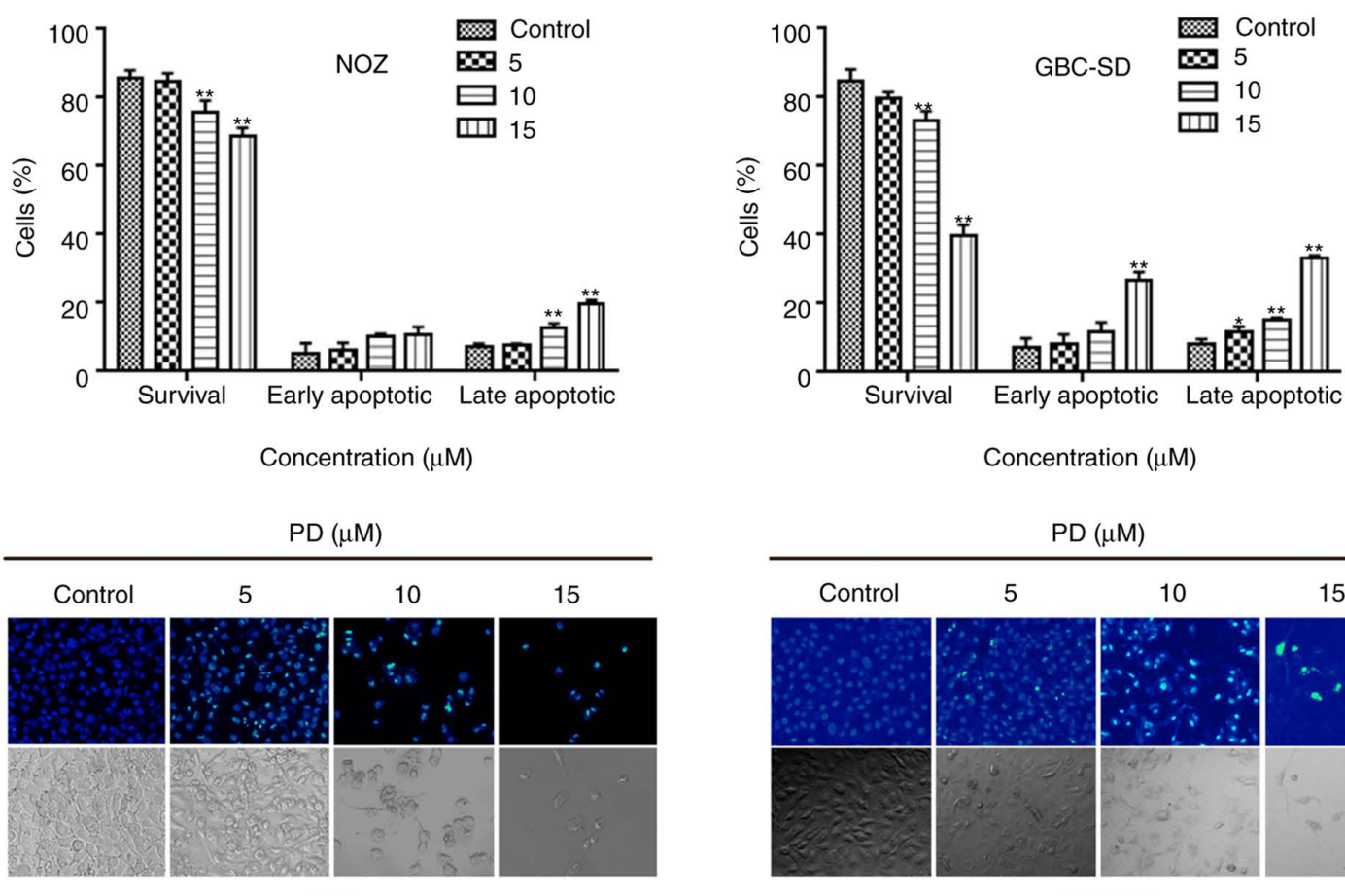

$\mathrm{NOZ}$

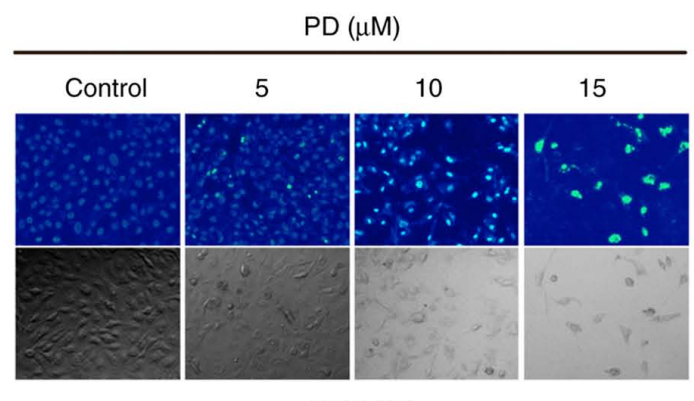

GBC-SD

Figure 3. PD induces apoptosis in GBC cells. (A) Flow cytometry was used to analyze PD-treated GBC cells. FITC single-positive scatters in the lower right quadrant are early apoptotic cells, FITC and PI double-positive scatters in the upper right quadrant are late apoptotic (including necrotic) cells. (B) The percentage of apoptotic cells expressed as the mean \pm SD. (C) Nuclear morphology was observed using fluorescence microscopy after staining with Hoechst 33342 (magnification, $\mathrm{x} 200$ ). The experiments were performed three times separately. ${ }^{*} \mathrm{P}<0.05,{ }^{* * *} \mathrm{P}<0.01$ vs. control. PD, Platycodin $\mathrm{D}$; GBC, gallbladder cancer.

were selected for subsequent experiments. A colony forming assay was performed to further investigate the colony forming ability of PD-treated GBC cells. The results indicated that PD had a negative effect on the ability of GBC cells to form colonies (Fig. 2B). Additionally, the PD-treated groups developed fewer clones than those in the control group (Fig. 2C). When treated with $5 \mu \mathrm{mol} / 1$ of $\mathrm{PD}$, a significant decrease in colonies was observed in NOZ cells, while a significant decrease in colonies was observed in GBC-SD cells when the cells were treated with $10 \mu \mathrm{mol} / 1$ of PD (Fig. 2C).

$P D$ induces apoptosis, chromatin condensation and mitochondrial dysfunction in GBC cells. To assess the potential mechanisms of action behind PD-mediated growth inhibition, PD-treated GBC cells were analyzed using flow cytometry (Fig. 3A). As the drug concentration increased, the proportion of apoptotic cells also increased, while the percentage of surviving cells was reduced (Fig. 3B). Subsequently, the morphology of the nuclei was analyzed using Hoechst 33342 staining. In the control group, the morphology of the cells was normal and the chromatin was uniformly distributed, while the chromatin in the PD-treated group were markedly aggregated and broken (Fig. 3C). Subsequently, Mito-Tracker green was used to stain the mitochondria. After treatment, bright green fluorescence was observed in the control group, while the fluorescence intensity of the PD-treated group was visibly reduced (Fig. 4A). 
A

\begin{tabular}{cccc}
\multicolumn{5}{c}{$\mathrm{PD}(\mu \mathrm{M})$} \\
\hline Control & 5 & 10 & 15
\end{tabular}
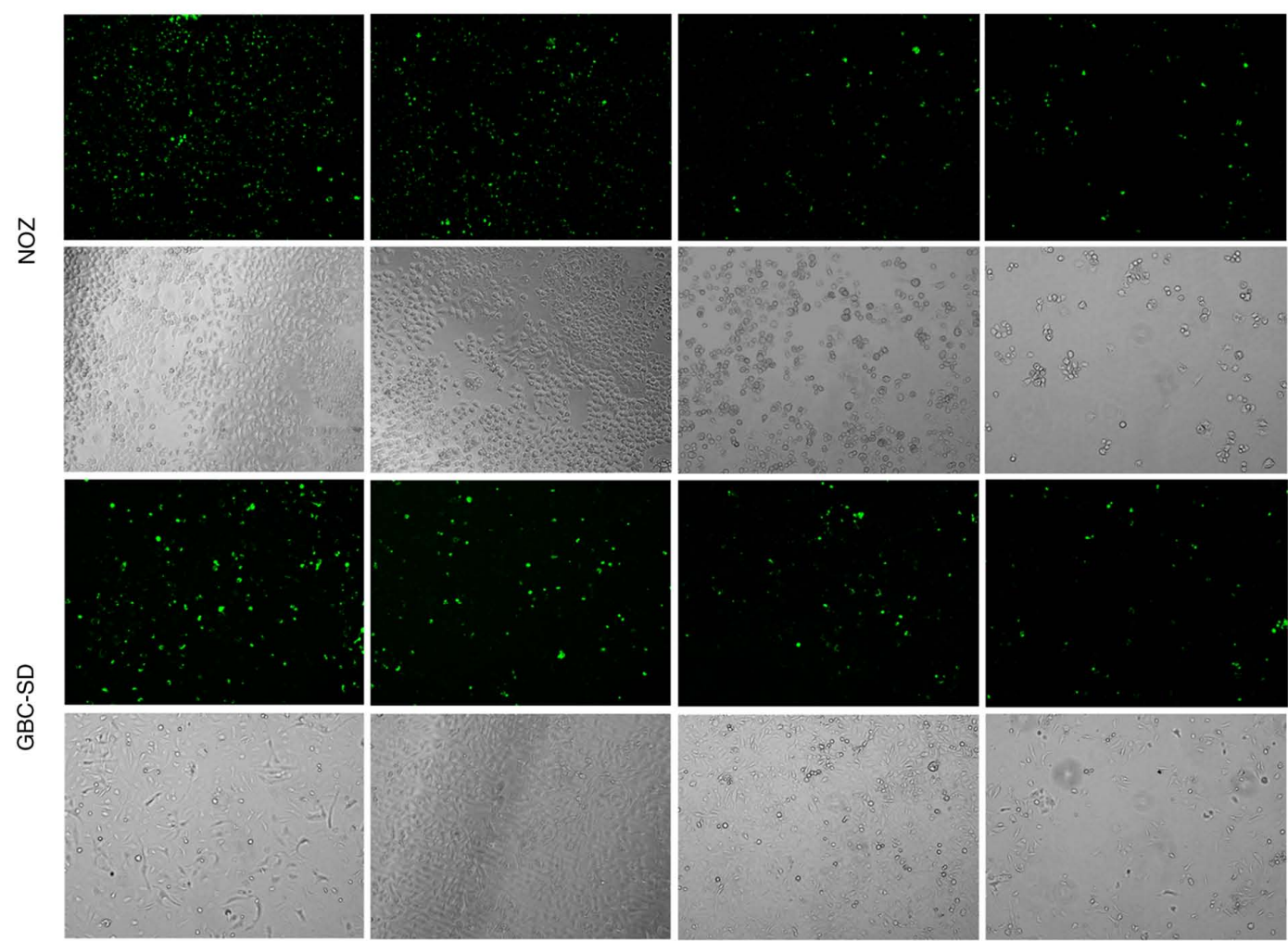

B
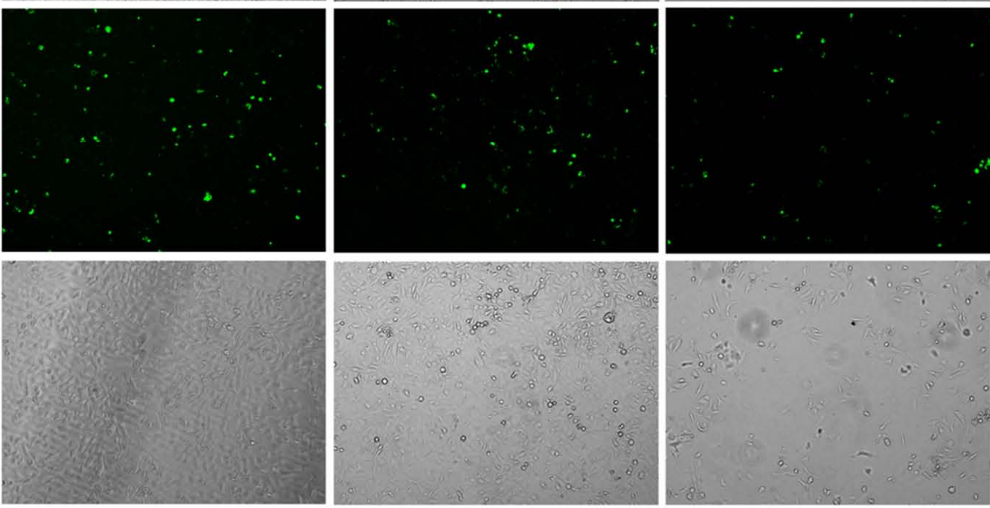

PD $(\mu \mathrm{M})$

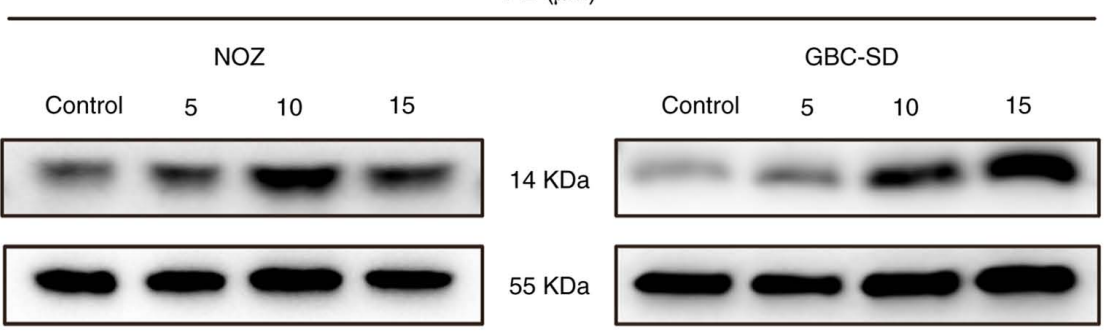

Figure 4. PD induces mitochondrial dysfunction in gallbladder cancer cells. (A) Mitochondrial numbers were observed using fluorescence microscopy after staining with Mito-Tracker Green (magnification, x100). (B) Cytochrome $c$ expression was detected using western blotting. PD, Platycodin D.

Additionally, cytochrome $c$ expression was higher in the PD-treated groups than that in the control group (Fig. 4B).

$P D$ inhibits the migration and invasion of $G B C$ cells. To explore the influence of PD on the migratory and invasive abilities of GBC cells, cell migration and invasion assays were performed. Compared with the control group, PD treatment (10 and $15 \mu \mathrm{mol} / \mathrm{l}$ ) markedly suppressed the migration numbers of NOZ and GBC-SD cells (Fig. 5A) and the difference was statistically significant $(\mathrm{P}<0.01$; Fig. $5 \mathrm{~B})$. In addition, in the cell invasion assay, $P D$ treatment led to a significant anti-invasion effect in GBC cells and this effect was dose-dependent (Fig. 5C and D). Additionally, western blotting analysis confirmed that MMP-2 and MMP-9 had low expression in PD-treated GBC cells compared with the control group (Fig. 5E). These data indicated that PD inhibited the migration and invasion of GBC cells.

$P D$ induces $G_{2} / M$ phase arrest via regulation of the expression levels of proteins associated with the cell cycle in GBC cells.
To further understand how PD affected the proliferation of GBC cells, flow cytometry was performed to measure the proportion of PD-treated GBC cells at different cell cycle stages (Fig. 6A). When cells were treated with $10 \mu \mathrm{mol} / \mathrm{l} \mathrm{PD}$, the proportion of cells in $\mathrm{G}_{2} / \mathrm{M}$ phase increased significantly, while the proportion of cells in $\mathrm{G}_{0} / \mathrm{G}_{1}$ phase decreased in both cell lines (Fig. 6B). This suggested that PD inhibited the cell cycle progression of GBC cells. Next, the levels of proteins that are closely associated with the cell cycle, such as cyclin B1 and CDK1, were examined. The expression levels of these proteins in GBC cells were markedly decreased compared with the control group (Fig. 6C). Therefore, PD may induce $G_{2} / M$ phase arrest in GBC cells to inhibit cell proliferation.

PD may induce apoptosis through the JNK signaling pathway in NOZ and GBC-SD cells. Caspase family and Bcl-2 family proteins are both important in the regulation of apoptosis (19). To further elucidate how PD induced apoptosis in GBC cells, 

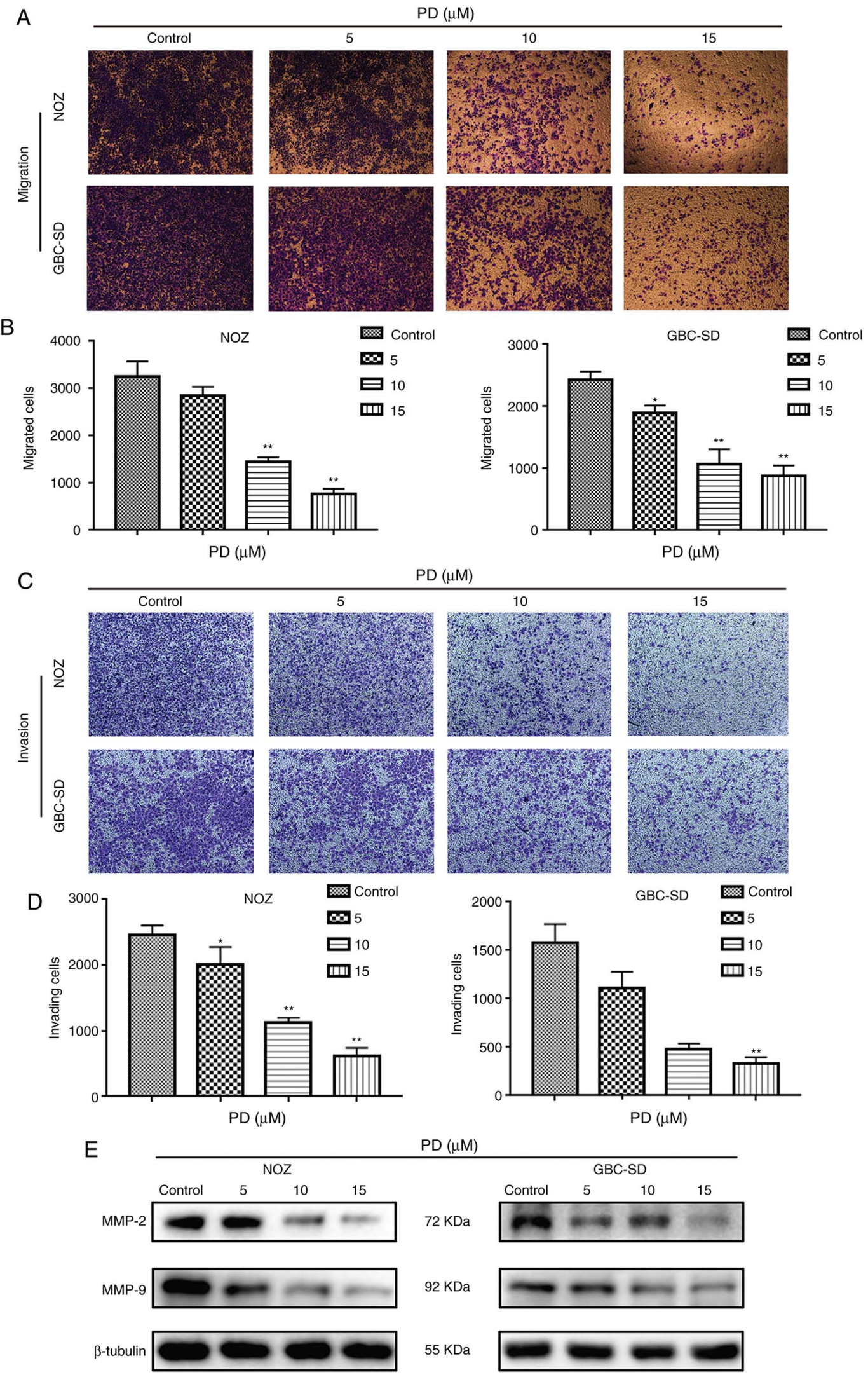

Figure 5. PD inhibits the migration and invasion of gallbladder cancer cells. (A) Migrative ability was determined via cell migration assays, and the migrated cells were stained and observed (magnification x100). (B) Number of migrated cells was counted as shown. (C) Invasive ability was determined via cell invasion assays, and the invaded cells were stained and observed (magnification x100). (D) Number of invading cells was counted as shown. (E) MMP-2 and MMP-9 expression was detected via western blotting. Each experiment was repeated three times independently. ${ }^{*} \mathrm{P}<0.05,{ }^{* *} \mathrm{P}<0.01$ vs. control. PD, Platycodin D.

the expression levels of apoptosis-associated proteins were investigated. It was observed that the expression levels of Bax, cytochrome $c$, cleaved caspase- 9 and cleaved caspase- 3 were increased with an increased concentration of PD, while Bcl-2 
A $\mathrm{PD}(\mu \mathrm{M})$

\begin{tabular}{llcc}
\hline Control & 5 & 10 & 15
\end{tabular}
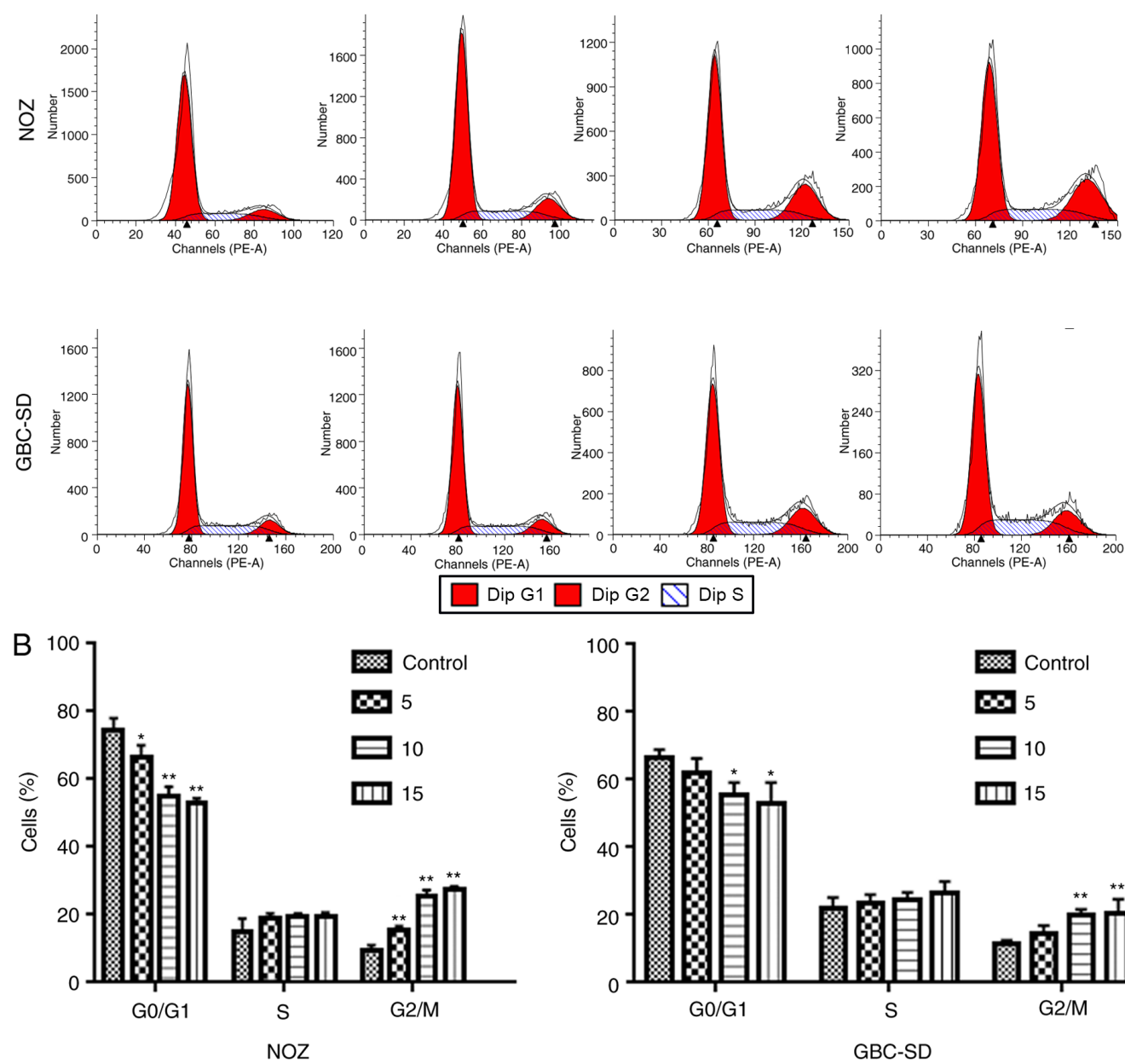

Dip G2 $\triangle$ Dip S

C
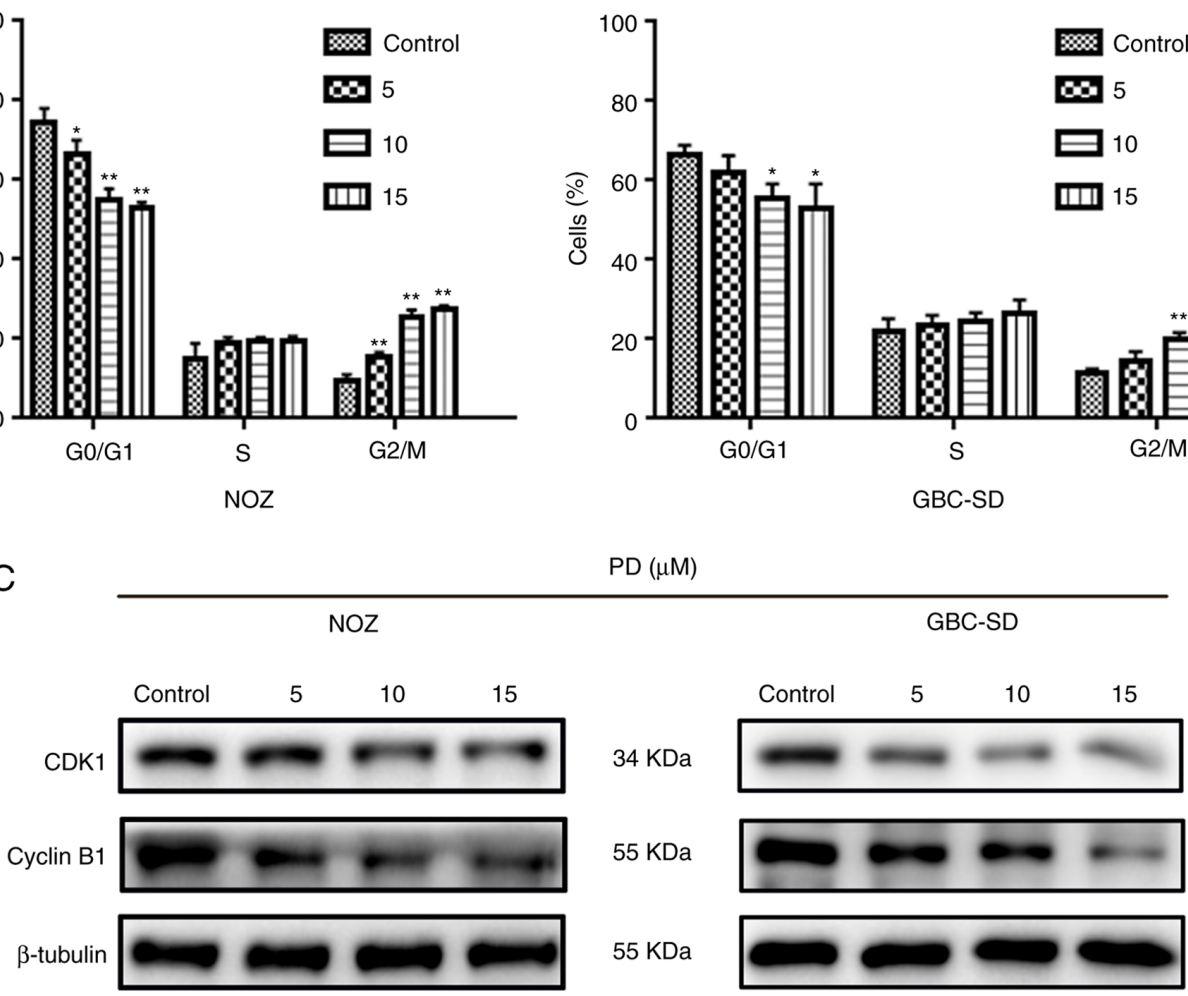

Figure 6. PD induces $\mathrm{G}_{2} / \mathrm{M}$ phase arrest in gallbladder cancer cells. (A) The percentage of cells in each cell cycle phase was detected using flow cytometry. (B) Data are expressed as the mean \pm SD. (C) Cyclin B1 and CDK1 expression was detected using western blotting. The data are presented as the mean \pm SD from three independent experiments. ${ }^{*} \mathrm{P}<0.05,{ }^{* * *} \mathrm{P}<0.01$ vs. control. PD, Platycodin D; CDK1, cyclin-dependent kinase 1.

expression was decreased with an increased concentration of PD compared with the control group (Figs. 4B and 7A). According to a previous study, the Bax/Bcl-2 ratio is a key factor in the regulation of the apoptotic process (20). In the present study, PD decreased the expression levels of the anti-apoptotic protein $\mathrm{Bcl}-2$ and increased those of the pro-apoptotic protein Bax, thereby decreasing the ratio of Bcl-2/Bax (Fig. 7B). Additionally, it was observed that p-JNK expression was upregulated, while JNK expression was not markedly changed. In summary, the present results suggested that PD may induce apoptosis by initiating mitochondrial destruction through the JNK signaling pathway in GBC cells.

\section{Discussion}

Previous studies have suggested that PD can suppress the proliferation and development of tumor cells, including prostate cancer (10), lung cancer (21) and liver cancer (22) cells, through various mechanisms, such as inhibiting cancer cell proliferation (16), inducing cell apoptosis (10), arresting cell cycle (12), 
A
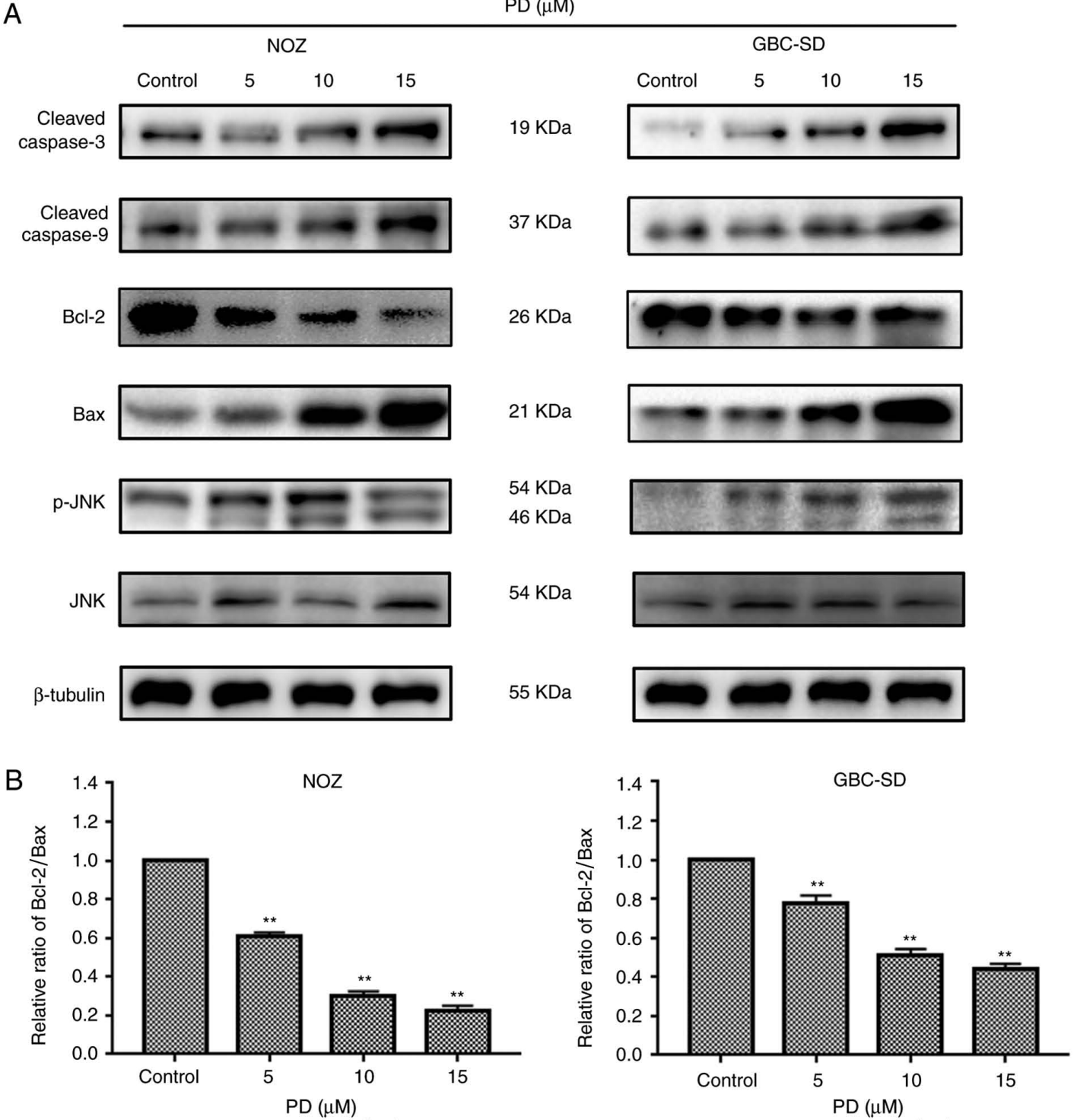

Figure 7. PD induces apoptosis through the JNK signaling pathway in NOZ and GBC-SD cells. (A) NOZ and GBC-SD cells were treated with different concentrations of PD $(0,5,10$ and $15 \mu \mathrm{mol} / \mathrm{l})$ for $48 \mathrm{~h}$. Protein expression levels were determined using western blotting. (B) Relative ratio of Bcl-2/Bax (the $\mathrm{Bcl}-2 / \mathrm{Bax}$ value of different drug concentration group was divided by the $\mathrm{Bcl}-2 / \mathrm{Bax}$ value of the control group to obtain a ratio and the $\mathrm{Bcl}-2 / \mathrm{Bax}$ value of the control group was set as 1). ${ }^{* *} \mathrm{P}<0.01$ vs. control. PD, Platycodin D; p-JNK, phosphorylated JNK.

inhibiting metastasis (17) and autophagy (18). However, to the best of our knowledge, there is currently no research on the influence of PD on GBC cells. The present study assessed the antitumor activity of PD using MTT and clone forming assays, and revealed that $\mathrm{PD}$ significantly inhibited the proliferation of GBC cells in a time- and concentration-dependent manner. Subsequently, several experiments were performed, including flow cytometry and nuclear staining with Hoechst 33342, which revealed that the amount of PD-induced apoptotic cells increased in a dose-dependent manner.

Invasiveness is an important feature of malignant tumors. With the help of cell migration and invasion assays, the present study demonstrated that the migratory and invasive abilities of GBC cells were inhibited by PD. MMP-2 and MMP-9 are closely associated with the migratory and invasive abilities of tumor cells, mainly through the hydrolysis of basement membrane components (23). Subsequently, western blotting revealed that the expression levels of MMP-2 and MMP-9 were decreased in PD-treated compared with the untreated GBC cells.

Apoptosis is a complex pathophysiological process involving several factors and proteins, such as the Bcl-2 (24) and caspase family (25). The imbalance between the anti-apoptotic protein $\mathrm{Bcl}-2$ and the pro-apoptotic protein Bax is particularly important (26). A previous study has demonstrated that $\mathrm{Bcl}-2$ and Bax usually exist as heterodimers and jointly regulate apoptosis (27). Changes in the Bcl-2/Bax ratio serve a key role in mitochondrial-dependent apoptosis (28). When Bcl-2 is upregulated, it forms a large number of heterodimers with Bax, inhibiting the activity of Bax and slowing down the cell cycle $(29,30)$. With the upregulation of Bax, several Bax homodimers are formed, which induce the release of cytochrome $c$ into the cytoplasm; activate caspase-9 and caspase-3; promote the cleavage of caspase-3; and initiate the caspase cascade, resulting in apoptosis $(31,32)$. Therefore, the detection of cleaved caspase- 3 is considered a reliable marker 
of cell death and apoptosis (33). In the present study, it was demonstrated that elevated PD levels increased the expression levels of Bax, cytochrome $c$, cleaved caspase-9 and cleaved caspase-3 in NOZ and GBC-SD cells. The mechanism of action by which PD induces the apoptosis of GBC cells may be associated with the regulation of the apoptosis signaling pathways of Bax, Bcl-2 and caspase-3. The present study revealed that p-JNK expression levels were increased in PD-treated GBC cells, while JNK protein expression levels were unchanged, suggesting that PD-treated GBC cells were activated by the JNK signaling pathway and that this pathway may mediate mitochondrial apoptosis (34), further confirming the hypothesis of the present study. In addition to the $\mathrm{G}_{1} / \mathrm{S}$ checkpoint, the $\mathrm{G}_{2} / \mathrm{M}$ checkpoint is an important cell cycle checkpoint (35). The CDK1-cyclin B1 complex is a protein kinase complex necessary for $\mathrm{G}_{2} / \mathrm{M}$ phase transition (36). With the help of cell cycle analysis, the present study revealed that PD arrested GBC cells in the $G_{2} / M$ phase. Western blot analysis indicated that the expression levels of $\mathrm{CDK} 1$ and cyclin $\mathrm{B} 1$ protein were decreased in PD-treated compared with untreated cells.

There are several limitations in the present study. Firstly, although the antitumor effects of PD on GBC cells were investigated in vitro, whether PD may serve the same role in vivo remains unknown. Secondly, the present study hypothesized that the JNK signaling pathway may be involved in the regulation of PD on GBC cell apoptosis, but how PD may activate the JNK signaling pathway and its upstream genes remains unclear.

In summary, the present results demonstrated the ability of PD to suppress the invasion of GBC cells and to induce apoptosis through the JNK signaling pathway and $\mathrm{G}_{2} / \mathrm{M}$ phase arrest, resulting in marked antitumor effects. Therefore, PD represents a novel chemotherapy drug that may potentially be used for the treatment of GBC.

\section{Acknowledgements}

Not applicable.

\section{Funding}

The present study was funded by the National Natural Science Foundation of China (grant no. 81372642).

\section{Availability of data and materials}

The datasets used and/or analyzed during the current study are available from the corresponding author on reasonable request.

\section{Authors' contributions}

JW and TZ designed the study. XZ performed the literature search. XZ and TZ performed the experiments. ZH, DZ, LJ and $\mathrm{CH}$ performed the data analysis and revised the manuscript. XZ was a major contributor in writing the manuscript. All authors read and approved the final manuscript.

\section{Ethics approval and consent to participate}

Not applicable.

\section{Patient consent for publication}

Not applicable.

\section{Competing interests}

The authors declare that they have no competing interests.

\section{References}

1. Kanthan R, Senger JL, Ahmed S and Kanthan SC: Gallbladder cancer in the 21st century. J Oncol 2015: 967472, 2015.

2. Are C, Ahmad H, Ravipati A, Croo D, Clarey D, Smith L, Price RR, Butte JM, Gupta S, Chaturvedi A and Chowdhury S: Global epidemiological trends and variations in the burden of gallbladder cancer. J Surg Oncol 115: 580-590, 2017.

3. Ma MZ, Li CX, Zhang Y, Weng MZ, Zhang MD, Qin YY, Gong W and Quan ZW: Long non-coding RNA HOTAIR, a c-myc activated driver of malignancy, negatively regulates miRNA-130a in gallbladder cancer. Mol Cancer 13: 156, 2014.

4. Weng M, Gong W, Ma M, Chu B, Qin Y, Zhang M, Lun X, McFadden G, Forsyth P, Yang Y and Quan Z: Targeting gallbladder cancer: Oncolytic virotherapy with myxoma virus is enhanced by rapamycin in vitro and further improved by hyaluronan in vivo. Mol Cancer 13: 82, 2014.

5. Millimouno FM, Dong J, Yang L, Li J and Li X: Targeting apoptosis pathways in cancer and perspectives with natural compounds from mother nature. Cancer Prev Res (Phila) 7: 1081-1107, 2014

6. Cragg GM and Newman DJ: Plants as a source of anti-cancer agents. J Ethnopharmacol 100: 72-79, 2005.

7. Balunas MJ and Kinghorn AD: Drug discovery from medicinal plants. Life Sci 78: 431-441, 2005.

8. Chin YW, Balunas MJ, Chai HB and Kinghorn AD: Drug discovery from natural sources. AAPS J 8: E239-E253, 2006.

9. Tada A, Kaneiwa Y, Shoji J and Shibata S: Studies on the saponins of the root of platycodon grandiflorum A. De candolle. I. Isolation and the structure of platycodin-D. Chem Pharm Bulletin (Tokyo) 23: 2965-2972, 1975

10. Zhou R, Lu Z, Liu K, Guo J, Liu J, Zhou Y, Yang J, Mi M and $\mathrm{Xu} \mathrm{H}$ : Platycodin D induces tumor growth arrest by activating FOXO3a expression in prostate cancer in vitro and in vivo. Curr Cancer Drug Targets 14: 860-871, 2015.

11. Xu C, Sun G, Yuan G, Wang R and Sun X: Effects of platycodin $\mathrm{D}$ on proliferation, apoptosis and PI3K/akt signal pathway of human glioma U251 cells. Molecules 19: 21411-21423, 2014.

12. Kim MO, Moon DO, Choi YH, Lee JD, Kim ND and Kim GY: Platycodin D induces mitotic arrest in vitro, leading to endoreduplication, inhibition of proliferation and apoptosis in leukemia cells. Int J Cancer 122: 2674-2681, 2008.

13. Li T, Xu WS, Wu GS, Chen XP, Wang YT and Lu JJ: Platycodin $\mathrm{D}$ induces apoptosis, and inhibits adhesion, migration and invasion in hepG2 hepatocellular carcinoma cells. Asian Pac J Cancer Prev 15: 1745-1749, 2014.

14. Yu JS and Kim AK: Platycodin D induces apoptosis in MCF-7 human breast cancer cells. J Med Food 13: 298-305, 2010.

15. Chun J, Joo EJ, Kang M and Kim YS: Platycodin D induces anoikis and caspase-mediated apoptosis via p38 MAPK in AGS human gastric cancer cells. J Cell Biochem 114: 456-470, 2013.

16. Ahn KS, Noh EJ, Zhao HL, Jung SH, Kang SS and Kim YS: Inhibition of inducible nitric oxide synthase and cyclooxygenase II by platycodon grandiflorum saponins via suppression of nuclear factor-kappaB activation in RAW 264.7 cells. Life Sci 76: 2315-2328, 2005.

17. Chun $\mathrm{J}$ and Kim YS: Platycodin D inhibits migration, invasion, and growth of MDA-MB-231 human breast cancer cells via suppression of EGFR-mediated akt and MAPK pathways. Chem Biol Interact 205: 212-221, 2013.

18. Li T, Tang ZH, Xu WS, Wu GS, Wang YF, Chang LL, Zhu H, Chen XP, Wang YT, Chen Y and Lu JJ: Platycodin D triggers autophagy through activation of extracellular signal-regulated kinase in hepatocellular carcinoma HepG2 cells. Eur J Pharmacol 749: 81-88, 2015.

19. Cosulich SC, Savory PJ and Clarke PR: Bcl-2 regulates amplification of caspase activation by cytochrome $c$. Curr Biol 9: 147-150, 1999. 
20. Nuñez G and Clarke MF: The Bcl-2 family of proteins: Regulators of cell death and survival. Trends Cell Biol 4: 399-403, 1994.

21. Li T, Chen X, Chen X, Ma DL, Leung CH and Lu JJ: Platycodin $D$ potentiates proliferation inhibition and apoptosis induction upon AKT inhibition via feedback blockade in non-small cell lung cancer cells. Sci Rep 6: 37997, 2016.

22. Li T, Xu XH, Tang ZH, Wang YF, Leung CH, Ma DL, Chen XP, Wang YT, Chen Y and Lu JJ: Platycodin D induces apoptosis and triggers ERK- and JNK-mediated autophagy in human hepatocellular carcinoma BEL-7402 cells. Acta Pharmacol Sin 36 1503-1513, 2015.

23. Bauvois B: New facets of matrix metalloproteinases MMP-2 and MMP-9 as cell surface transducers: Outside-in signaling and relationship to tumor progression. Biochim Biophys Acta 1825: 29-36, 2012.

24. Cory S and Adams JM: The Bcl2 family: Regulators of the cellular life-or-death switch. Nat Rev Cancer 2: 647-656, 2002.

25. Thornberry NA and Lazebnik Y: Caspases: Enemies within. Science 281: 1312-1316, 1998.

26. Campbell KJ and Tait SW: Targeting BCL-2 regulated apoptosis in cancer. Open Biol 8: 180002, 2018.

27. Wang W, Guo Q, You Q, Zhang K, Yang Y, Yu J, Liu W, Zhao L, $\mathrm{Gu} \mathrm{H}, \mathrm{Hu} \mathrm{Y}$, et al: Involvement of bax/bcl-2 in wogonin-induced apoptosis of human hepatoma cell line SMMC-7721. Anticancer Drugs 17: 797-805, 2006

28. Jin CY, Moon DO, Choi YH, Lee JD and Kim GY: Bcl-2 and caspase-3 are major regulators in agaricus blazei-induced human leukemic U937 cell apoptosis through dephoshorylation of akt. Biol Pharm Bull 30: 1432-1437, 2007.
29. Vaux DL, Cory S and Adams JM: Bcl-2 gene promotes haemopoietic cell survival and cooperates with c-myc to immortalize pre-B cells. Nature 335: 440-442, 1988

30. Cheng N, Janumyan YM, Didion L, Van Hofwegen C, Yang E and Knudson CM: Bcl-2 inhibition of T-cell proliferation is related to prolonged T-cell survival. Oncogene 23: 3770-3780, 2004.

31. Pistritto G, Trisciuoglio D, Ceci C, Garufi A and D'Orazi G: Apoptosis as anticancer mechanism: Function and dysfunction of its modulators and targeted therapeutic strategies. Aging (Albany NY) 8: 603-619, 2016.

32. Elmore S: Apoptosis: A review of programmed cell death. Toxicol Pathol 35: 495-516, 2007.

33. Zaman S, Wang R and Gandhi V: Targeting the apoptosis pathway in hematologic malignancies. Leuk Lymphoma 55: 1980-1992, 2014

34. Xia Z, Dickens M, Raingeaud J, Davis RJ and Greenberg ME: Opposing effects of ERK and JNK-p38 MAP kinases on apoptosis. Science 270: 1326-1331, 1995.

35. Stark GR and Taylor WR: Control of the G2/M transition. Mol Biotechnol 32: 227-248, 2006.

36. Malumbres M: Cyclin-dependent kinases. Genome Biol 15: 122, 2014.

(c) (1) 9 This work is licensed under a Creative Commons Attribution-NonCommercial-NoDerivatives 4.0 International (CC BY-NC-ND 4.0) License. 